\title{
"The risk management practices in the manufacturing SMEs in Cape Town"
}

\begin{tabular}{|c|c|}
\hline AUTHORS & $\begin{array}{l}\text { Clinton Mbuyiselo Sifumba } \\
\text { Kevin Boitshoko Mothibi } \\
\text { Anthony Ezeonwuka } \\
\text { Siphesande Qeke } \\
\text { Mamorena Lucia Matsoso }\end{array}$ \\
\hline ARTICLE INFO & $\begin{array}{l}\text { Clinton Mbuyiselo Sifumba, Kevin Boitshoko Mothibi, Anthony Ezeonwuka, } \\
\text { Siphesande Qeke and Mamorena Lucia Matsoso (2017). The risk management } \\
\text { practices in the manufacturing SMEs in Cape Town. Problems and Perspectives } \\
\text { in Management, 15(2-2), 386-403. doi:10.21511/ppm.15(2-2).2017.08 }\end{array}$ \\
\hline DOI & http://dx.doi.org/10.21511/ppm.15(2-2).2017.08 \\
\hline RELEASED ON & Tuesday, 05 September 2017 \\
\hline RECEIVED ON & Wednesday, 23 March 2016 \\
\hline ACCEPTED ON & Friday, 27 January 2017 \\
\hline LICENSE & $\begin{array}{l}(c) \text { EY-No } \\
\text { This work is licensed under a Creative Commons Attribution-NonCommercial } 4.0 \\
\text { International License }\end{array}$ \\
\hline JOURNAL & "Problems and Perspectives in Management" \\
\hline ISSN PRINT & $1727-7051$ \\
\hline ISSN ONLINE & $1810-5467$ \\
\hline PUBLISHER & LLC "Consulting Publishing Company "Business Perspectives" \\
\hline FOUNDER & LLC "Consulting Publishing Company "Business Perspectives" \\
\hline
\end{tabular}

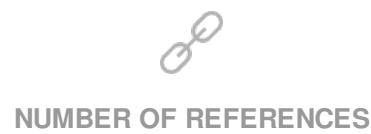

70

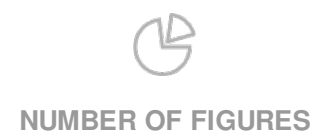

0

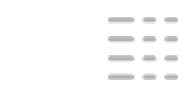

NUMBER OF TABLES

5

(c) The author(s) 2023. This publication is an open access article. 


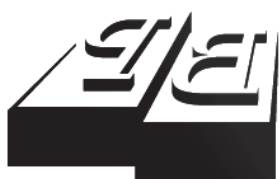

BUSINESS PERSPECTIVES

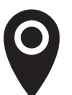

LLC "CPC "Business Perspectives" Hryhorii Skovoroda lane, 10, Sumy, 40022, Ukraine

www.businessperspectives.org

Received on: $23^{\text {th }}$ of March, 2016 Accepted on: $27^{\text {th }}$ of January, 2017

(C) Clinton Mbuyiselo Sifumba, Kevin Boitshoko Mothibi, Anthony Ezeonwuka, Siphesande Qeke, Mamorena Lucia Matsoso, 2017
Clinton Mbuyiselo Sifumba (South Africa), Kevin Boitshoko Mothibi (South Africa), Anthony Ezeonwuka (South Africa), Siphesande Qeke (South Africa), Mamorena Lucia Matsoso (South Africa)

\section{THE RISK MANAGEMENT PRACTICES IN THE MANUFACTURING SMES IN CAPE TOWN}

\begin{abstract}
Risk management is one of the prominent issues which are pivotal to the success of a business and may adversely affect profitability if not properly practised. Therefore, the main objective of this paper was to determine risk management practices in manufacturing SMEs in Cape Town. The research conducted was quantitative in nature and constituted the collection of data from 74 SME leaders, all of whom had to adhere to a list of strict delineation criteria. All data collected were thoroughly analyzed through means of descriptive statistics. From the findings made, it is clear that SMEs in the manufacturing sector do in fact understand risk management initiatives applicable to 'manage' their respective businesses towards sustainability, but not to a large extent. It was found that respondents are unaware of the elements which make risk management effective, which ultimately aids to the development of problems for SMEs. All employees, managers and owners must coordinate their efforts together to identify and manage organizational risks within their ambit to obtain total risk coverage, as well as provide assurance that these risks are effectively managed from a coordinated approach. Further studies may be carried out to identify measures that can be taken to improve the effectiveness of risk management practices in SMEs
\end{abstract}

\section{Keywords}

small and medium enterprises, manufacturing, performance measurement, risk, risk management, risk management practices, sustainability

JEL Classification L25

Kevin Boitshoko Mothibi, Bachelors Degree in Internal Auditing, Cape Peninsula University of Technology, South Africa.

Anthony Ezeonwuka, Bachelors Degree in Internal Auditing, Cape Peninsula University of Technology, South Africa.

Siphesande Qeke, Bachelors Degree in Internal Auditing, Cape Peninsula University of Technology, South Africa.

Mamorena Lucia Matsoso, Masters in Cost and Management Accountin, Lecturer, School of Accounting Sciences, Cape Peninsula University of Technology, South Africa

\section{(ㄷ)(1) $(8)$}

This is an Open Access article, distributed under the terms of the Creative Commons Attribution-NonCommercial 4.0 International license, which permits re-use, distribution, and reproduction, provided the materials aren't used for commercial purposes and the original work is properly cited.

\section{INTRODUCTION}

Risk management is still not prevalent among SMEs, particularly in the manufacturing sector; although it is not new, it has recently become a growing subject in supply-chain management (Lavatre, Gunasekaran, \& Spalanzani, 2012). SMEs play a significant role in the economic growth and sustainable development of any economy (Kongolo, 2010; Abor \& Quartey, 2010; Tehseen \& Ramayah, 2015) and contribute 51 to 57 percent towards the Gross Domestic Product (GDP) in the South African economy. As such, government utilizes SMEs to achieve three main objectives which are: alleviating poverty, creating employment opportunities and promoting economic growth (South Africa, 1996). This statement was further complemented by Joubert, Schoeman, and Blignaut (1999) who stated that SMEs are often considered as the backbone of the economy and the main driver of economic growth in the country (Apulu, Lathen, \& Moreton, 2011). SMEs are not only seen as an employment creator, but they also act as an absorbent of retrenched people coming from the private and public sectors (Ntsika, 2001). Furthermore, SMEs are also deemed as a mechanism to narrow the 'gap' between rich and poor, and reduce the 'backlog' of the previously disadvantaged (Bolton, 2006). 
Unfortunately South African SMEs are estimated to have an overall failure rate of which many fail to go past the end of the second year of business establishment (Van Eeden, Viviers, \& Venter, 2003; Cant \& Wiid, 2013). In support of these authors, Rogerson (2013) is of the opinion that SMEs do not survive beyond their first five years of existence. The major factors that contribute to the current SME failure rate include, but are not limited to: the lack of appropriate management skills and inadequate capital (Everett \& Watson, 1998; Olawale \& Garwe, 2010). The aforementioned factors hold a close relevancy to risk management. This high failure rate has led to investors and banks shying away from funding SMEs; as a result, SMEs are regarded as very risky (Terungwa, 2012; Ahmmed \& Bown, 2016).

A risk is a possibility of something happening that will impact upon objectives of an organization (Manu, 2005). Risk may also be defined as the probability of loss and the magnitude of that loss to the detriment of an organization and/or a person (Harland, Brenchley, \& Walker, 2003). Risks are measured in terms of probability (likelihood) and extent (materiality), and will in most cases adversely affect the organization (COSO, 2004). The risk process entails identifying, analyzing and evaluating the risk that pertains to the organization, and which may hinder the entity from achieving its objectives. Risk is one of the recurrent problems that makes SMEs unattractive to investors. There are many types of risk that are encountered in business. Some risks are controllable, while others are not, and some are foreseeable, while some are unforeseeable. Some risks have minimal impact on the business, while some threaten the durability of a business. The nature of risk, therefore, varies according to the industry in question. The onus is, therefore, on the owners to identify the risk prevalent in their businesses and make efforts to embark on good risk management techniques. Business leaders do not identify imminent risks faced by small businesses due to the lack of proper internal controls and assurance activities (Noorvee, 2006; Prinsloo, Walker, Botha, Bruwer, \& Smit, 2015).

Risk management is defined as a process that includes the identification of potential events that may influence objectives and which drives assessments and response plan processes (COSO, 2004). Risk management supports the latter (risk) by the identification and management of potential events to provide reasonable assurance regarding the achievement of objectives (COSO, 2004). Furthermore, Enterprise Risk Management (ERM) is to ensure that these risks are managed effectively all together, as opposed to managing these risks in silos (Beasley, Chen, Nune, \& Wright, 2006). Lavestre et al. (2012) aver that these risks affect several branches of management including operations, strategy, supply, customer relations, financial markets, legal, fiscal and regulatory requirements, asset impairment and strategy, amongst others. The inability of business owners to apply the risk management process, in an acceptable manner, has contributed in risk management becoming one of the factors that leads to lowering the sustainability of SMEs (Terungwa, 2012). Risk management is an integral part of good business governance. It is simply protecting the business from possible negative occurrences, as well as recognizing opportunities and capitalizing on them when they arise (Aruwa, 2005). More so, Ekwere (2016) asserts that there is a paucity of research in risk management for SMEs despite their economic and social contributions in society. Their informal structures and exposure to failure when faced with unexpected risks is also a concern and calls for practical and academic research in this field (Ekwere, 2016). Hence, the objective of this study is to ascertain risk-management practices in manufacturing SMEs in Cape Town. Thus, the research questions of this study are as follows: 1) What are the perceptions of SMEs about risk management? 2) What are SMEs risk management practices in their day-to-day operation of the businesses?

Taking the above into consideration, it is clear that risk management is of paramount importance. If risk management is rolled out and managed effectively and efficiently, it can help businesses become more sustainable.

This paper is categorized according to the literature review of small business overviews, risk management, supply chain management in SMEs and performance measures. Authors, then, discuss the design and methodology of the study, results and discussion and conclusion. Thereafter, practical implications and suggestions for further studies are also stated. 


\section{LITERATURE REVIEW}

\subsection{SME overview}

The latter definition groups SMEs in relation to size based on three criteria: 1) the number of employees, 2) the total annual turnover made, and 3) their estimated gross asset value (excluding fixed property). For the sake of clarity, the criteria for manufacturing SMEs are collaborated in Table 1 below:

SMEs are often established to improve the economy of the country in order to reduce the high unemployment rate, which would, in turn, eliminate poverty, while Mbonyane and Ladzani (2011) elucidate small businesses as the backbone of many economies across the globe. These statements were further complemented by Butcher (1999) who said that SMEs are pivotal to the growth and development of the South African economy. SMEs are inextricably linked to economic empowerment, job creation, and employment within disadvantaged communities (Davies, 2001). Small businesses are significant due to the important role they fulfil in terms of job creation for less skilled employees (SEDA, 2010). SMEs contribute approximately $30 \%$ towards the national GDP of South Africa and provide an estimated $80 \%$ of all local employment opportunities (National Credit Regulator, 2011). One of the large contributors to the country's Gross Domestic Product is the manufacturing sector of $30 \%$ and has the biggest potential to reduce the high unemployment rate and enhance national economic growth (Abor \& Quartey, 2010; Kongolo, 2010; Olawale \& Garwe, 2010). Kongolo (2010) points out that these entities account for $91 \%$ of all business entities operating in South Africa. These views were substantiated by claims that activities in the manufacturing sector are often considered the bedrock of an economy and a key driver of growth and development
(Urban \& Naidoo, 2012). Hence, it is no surprise that SMEs are regarded as catalysts for the development of any country (Abor \& Quartey, 2010). Albeit the above, one can immediately note that South African SMEs struggle when it comes to remaining as going-concern entities. Despite the significant contribution of SMEs in South Africa, the failure rate of these businesses within their first year of existence is very high (Fatoki \& Smit, 2011). There has been a slight improvement in recent times; however, $75 \%$ of South African SMEs have had to close their doors after operating for an average of 42 months (Fatoki, 2012; Ngary, Smit, Bruwer, \& Ukpere, 2014). Comparing the views of the authors mentioned above, it is evident that SMEs have significant sustainability issues that require attention from academics and practitioners to find amicable solutions that may lead to the growth and sustainability of SMEs. This phenomenon can be further tested (theoretically) in terms of the change in overall unemployment. The unemployment statistics for South Africa are provided below for the sake of reference:

Table 2. Unemployment statistics of South Africa

Source: Statistics South Africa (2011)

\begin{tabular}{l|c|c|c}
\hline $\begin{array}{c}\text { Unemployment } \\
\text { statistics }\end{array}$ & $\mathbf{2 0 1 2}$ & $\mathbf{2 0 1 1}$ & $\mathbf{2 0 1 0}$ \\
\hline $\begin{array}{l}\text { Unemployed } \\
\text { rate (estimated) }\end{array}$ & $24.90 \%$ & $25 \%$ & $24 \%$ \\
\hline $\begin{array}{l}\text { Population } \\
\text { (estimated) }\end{array}$ & $50,586,757$ & $49,091,100$ & $49,004,030$ \\
\hline $\begin{array}{l}\text { Unemployed } \\
\text { people } \\
\text { (estimated) }\end{array}$ & $12,596,103$ & $12,272,775$ & $11,760,968$ \\
\hline
\end{tabular}

A lot of factors are hindering the progress of manufacturing SMEs all over the world. The lack of entrepreneurial knowledge and business management skills is often credited as one of SMEs major failures (EL-Namaki, 1990; Scarborough \& Zimmerer, 1996). One of the contributing factors

Table 1. The categorization of manufacturing SME sizes

Source: South Africa (1996).

\begin{tabular}{|c|c|c|c|}
\hline $\begin{array}{l}\text { Enterprise } \\
\text { size }\end{array}$ & $\begin{array}{l}\text { Number of } \\
\text { employees }\end{array}$ & Total annual turnover & $\begin{array}{l}\text { Total gross asset value (excluding } \\
\text { fixed property) }\end{array}$ \\
\hline Medium & Between 51 and 200 & Between R10 000001 and R40 000000 & Between R3 750001 and R15 000000 \\
\hline Small & Between 21 and 50 & Between R4 000001 and R10 000000 & Between R1 500001 and R3 750000 \\
\hline Very small & Between 6 and 20 & Between R150 001 and R4 000000 & Between R100 000 and R1 500000 \\
\hline
\end{tabular}


affecting SMEs is the low levels of education and training, poor business skills and poor business efficiencies among SMEs (Yanta, 2001; Tumaini \& Zheng, 2011; Betchoo, 2015). Further economic factors, which adversely influence SMEs' business continuation statistics are: inadequate strategic planning processes; the lack of performance measurement systems; limited access to appropriate technologies; limited access to non-financial resources; lack of management skills and training, limited access to markets; and excessive government laws (Abor \& Quartey, 2010; Terziovski, 2010). SMEs struggle to access finance from South African banks (Smit \& Watkins, 2012) because of their perceived high level of risk (Kraus, Rigtering, Hughes, \& Hosman, 2012). In order to become more competitive and efficient, SMEs in the manufacturing sector, owners management will need to formalize (enhance) their internal structures and systems (Terziovski, 2010). In particular, the element of competition was also found to be an impeding economic factor for manufacturing SMEs to achieve their full potential in terms of development (Ngubane, Mayekiso, Sikota, Mafisthane, Matsoso, \& Bruwer, 2015). The latter is especially the case, since products can be manufactured (and imported) at a much 'cheaper' rate from countries such as China and India. This dispensation makes it extremely difficult for South African manufacturing SMEs to develop appropriate strategies to become 'worthy' competitors (Singh, Garg, \& Deshmark, 2010). One of the factors hindering progress of small businesses is that business leaders are not able to identify all the risk elements that have impact on their business activities (Smit \& Watkins, 2012).

\subsection{Risk}

Risk is categorized into three parts, namely:

- Inherent risk. It is a risk that is intrinsic to the organization's business. The susceptibility of a material misstatement, assuming no related internal control procedures are in place (COSO, 2004).

- Control risk. The risk that a material misstatement that could occur will not be prevented nor detected on a timely basis by internal controls (COSO, 2004).
- Detection risk. The risk that an internal or external auditor will not detect a material misstatement (COSO, 2004).

\subsection{Risk management in SMEs}

The realization of risk gives rise to the need for mitigation; the common term used to mitigate risks is a term called 'risk management'. Risk management is defined as "a process that includes the identification of potential events that may influence objectives, which drive assessments and response plan processes" (COSO, 2004). Risk management is a required practice in manufacturing SMEs to enable owners management to mitigate these risks, risk management practice is important, as it can either make or break a business from a profitability or liquidity perspective. Risk management supports the latter by the identification and management of potential events to provide reasonable assurance regarding the achievement of objectives (COSO, 2004). Furthermore, the identification and evaluation of actual and potential risks is to eliminate and/or mitigate identified risks which constitute risk management (Rao \& Goldsby, 2009). SMEs owner managers are so knowledgeable about their ventures, but are commonly not able to identify all the risk elements that have an impact on their business activities (Smit \& Watkins, 2012). Risk management is a major concern for all SMEs, especially those that are sensitive to business risk (risk in and around a business which may adversely impact such a business) and competition (Smit \& Watkins, 2012). If risks cannot be properly evaluated, risk management itself becomes the biggest risk of such an organization. Therefore, risk should be properly evaluated on an ongoing basis (de Bakker, Boonstra, \& Wortmann, 2010). Maholtra and Temponi (2010) emphasize that the growing interest in risk management is a result of the needs and challenges facing SMEs, including: stakeholders and entrepreneurs expecting sustainable value creation; the rate of business that is accelerating; the weak economy of the country; stakeholders and entrepreneurs that are tired of failure; and business leaders need the capability to calibrate and align the relationship between growth, risk and return (Olawale \& Garwe, 2010; Fatoki \& Smit, 2011; Smit \& Watkins, 2012). Establishing risk initiatives for manufacturing SMEs is criti- 
cal to the success of their endeavors. SMEs go to the ground very often because of high levels of non-application of risk management processes, unmanaged risks and worst case scenarios, and the inability to manage risks. However, Ekwere (2016) notes that the objective of risk management is not to prevent risk taking but to ascertain that risk is taken with a clear understanding and knowledge to enable its measurement and mitigation with an organization. SMEs are also found to have backward looking perspectives as opposed to a transformed and forward looking approach that promotes continuous improvement (Ching \& Colombo, 2014). According to Watt (2007), SME owners managers should take regard of the following steps in their risk management processes: 1) establish the SMEs risk strategy, 2) determine the SMEs risk appetite, 3) the identification and assessment of risk, and 4) the prioritization and management of risk.

Having an understanding of the risk management process surrounding the organization is useless if inadequate risk management initiatives are applied. Owners and managers of manufacturing SMEs need to take risk management as a process that utilizes internal controls as measures to mitigate and control risk pertaining to their organizations. Hence, owners and managers in SMEs need to be conversant with risk identification and analysis to manage risks from a diverse range of sources (Schultz, 2001). This statement by Schultz is complemented by Smit and Watkins (2012) who stipulate that SMEs which incorporate risk management are better equipped to exploit resources pertaining to their organizations, therefore, enabling SMEs to convert an expenditure activity into an activity that can yield a positive return (Hsu, Lien, \& Chen, 2013). According to Napp (2011), risk occurrence can be a danger to SMEs in continuity; it is of paramount importance that SMEs focus and try to implement comprehensive risk management. The main outcome of risk management is to reduce the number of threats that materialize into problems and to minimize the effect of those which do occur (Hillson, 2009). Taking the above into consideration, it is clear that risk management is of paramount importance. If risk management is managed effectively and efficiently, it can help businesses become more cost-effective.

\subsection{Supply chain risk management in SMEs}

Supply risk is regarded as an operational risk which covers matters of supply, deliveries, orders and short-term operational management (Lavastre et al., 2012), while supply-chain risk is more strategic and encompasses the management and flow of information, commodities throughout the supply chain, and the consequences for supply risk thereof. In their findings, Lavastre et al. (2012) found that SMEs make use of localised suppliers which limit their collaborative partnerships. They are less structured when compared to their larger counterparts; their risk management is highly unstructured. While supply chain risk management (SCRM) is defined as "the management of supply chain risk through coordination or collaboration among the supply chain partners so as to ensure profitability and continuity" (Tang, 2006; Tang \& Musa, 2011), the management of risk in the supply chains of SMEs, particularly in the manufacturing sector, is becoming more and more complex due to a diverse nature of uncertainties from material, financial and information flow in the supply chain (Tang \& Musa, 2011). Risk associated with single sourcing for material components, on the one hand, may be detrimental to the organization. Although flexible sourcing might incur hidden costs, they may negatively impact on the finances of the business. Financial risk, on the other hand, results from fluctuating tax rates and supplier selection and market development. While information risk is associated with communicating, the accurate information throughout the value chain (Faisal, Banwet, \& Shankar, 2007; Tang \& Musa, 2011) refers to information flow as the bond between material and financial. Hence, understanding the risk management practices of SMEs is inevitable so as to bring an awareness of the need for a positive risk management attitude and good practice towards an effective SCRM. Information risk may also be established at the application and organizational level and through the inability to protect information sharing within the organisation and other stakeholders in the value chain (Barry, 2004; Finch, 2004). However, these risks may be minimized through networking and collabo- 
rations among SMEs to attain the desired outcomes in their supply chain (Senik, Scott-Ladd, Entrekin, \& Adham, 2011). The authors of this paper acknowledge the importance of SCRM in the manufacturing sector, because SME manufacturers can never function in isolation to their partners and stakeholders. However, this study placed emphasis on the internal risk management practices.

\subsection{Performance measures}

Performance measures quantitatively tell us something important about our products, services, and the processes that produce them. They are a tool to help us understand, manage, and improve what our organizations do (Oak Ridge Associated Universities, 2005). The most comprehensive way to measure a risk management program including the risk management initiatives thereof, and the key considerations to quantify the effectiveness of the program to be asked according to Minsky (2012) entails: 1) number of systemic risks identified, 2) percentage of process areas involved in risk assessments, 3) percentage of key risks mitigated and 4) percentage of key risks monitored. The findings of Gupta (2011) place emphasis on the need for effective risk management to improve organizational performance. In relation to this study, performance measures would be the tools and techniques usable to ascertain risk management initiatives in manufacturing SMEs. These performance measures encompass sustainability, growth and the success rate in the management of hindering factors such as crime, training and employees' health.

In developing countries, successful SMEs are regarded as those who survive the first two years after establishment (Urban \& Naidoo, 2012). Skills are very important for the sustainability of any SMEs (Urban \& Naidoo, 2012), hence, skills upgrades should be of the highest importance for SMEs. They also advise that a lack of this element can devour SMEs to the ground as a business that lacks skills will lack capacity and efficiency, which will result in failure. Yanta (2001) shares the same sentiments towards skills being the determining factor for business success. This goes to show that if the employee inadequate skills risk is well managed, SMEs will survive their first two years and achieve all their planned goals and objectives; as such, this may serve as a performance measure.

Factors that indicate growth and sustainability according to Urban and Naidoo (2012) are as follows: employment growth over the past two years; employment growth against competitor over the past two years; growth in sales turnover over the past two years; growth in sales turnover against competitor over the past two year's growth profits; growth in market value over the past two years and growth in market value against competitor over the past two years. These observations were concluded after statistical and mathematical analyses were performed. One may argue that if risk management initiatives applied by SMEs are adequate, they will experience growth in their businesses and, as such, growth serves as a performance measure. Beyond growth and time survival, SMEs come head-to-head with pressing economic and socioeconomic hindrances. The survival of these hindrances would depict the adequacy of risk management initiatives in the SME environment. According to Mbonyane and Ladzani (2011), the hindrances faced by SMEs are: legal requirements not met; poor financial management; poor stock control (overtrading); poor crime prevention; poor access to credit; poor staff relations; poor infrastructure; and poor technological skills. Adequate risk management initiatives may mitigate all the above-stated hindrances and, as such, the failure and success rate on the abovementioned would delineate the adequacy of the risk management initiatives in SMEs.

From the above literature review and understanding of the subject at hand, one can conclude that there are three primary performance measures of an adequate risk management profile, these being: sustainability (survival time period); growth and profitability; and the successful management of hindering factors.

\section{DESIGN AND METHODOLOGY}

This research study took place in the form of a descriptive research with the main intention of describing SME manufacturing risk man- 
agement practices in Cape Town (Davis, 2014). The method was used to describe and examine causal relationships relating to risk management practices in the SME manufacturing sector within Cape Town. The researchers adopted quantitative research (positivism as part of the research paradigm) to obtain data to mitigate the identified research problem. This was done through means of disseminating questionnaires - mostly 'close-ended questions'. According to Watkins (2012), a questionnaire primarily falls within the ambit of the positivistic research paradigm. Questionnaires were used as a tool to assist the researchers in collecting large quantities of data.

The data collected were analyzed statistically by means of Excel and SPSS to serve as evidence for relevant findings of the research study. A total of 100 structured questionnaires was disseminated to all respondents around Cape Town, while 74 we collected and deemed valid for analysis.

\subsection{Population and sampling}

The study population consisted of SMEs in the manufacturing sector operating in Cape Town. The authors did not know their targeted population in the manufacture sector, so in this case the researchers adopted a non-probability sampling technique. According to these researchers (Jowah, 2011; Bryman, Bell, Hirschsohn, Dos Santos, Du Toit, Masenge, Van Aardt, \& Wagner, 2014), non-probability sampling occurs when the size of the population being studied by the researchers is unknown and not every unit of the population has a chance of being selected. Therefore researchers made use of 'non-statistical calculations' as a tool in order to draw a suitable sample size for their research study. Purposive sampling was used based on specific set criteria or a delineation of the research.

\subsection{Validity and reliability of the results}

The questionnaire was divided into three categories. Section A was biographic information of the sample used in the study. Section B was the perception of the SME owners and managers about risk management. This section contained 12 questions from which internal test of reliability was used and Cronbach's Alpha coefficient of .836 was obtained. Section C risk management practices. Sections C was made up of 11 variables, which provided Cronbach's Alpha coefficient of .876. These results prove to be highly reliable as the Cronbach's Alpha is close to 1 (Pietersen \& Maree, 2007; Jackson, 2009), while a Cronbach's Aplha close to 0 would depicts a lower internal reliability. The Cronbach's Alpha coefficient was also used as a measure of construct validity in this study (Koonin, 2014).

\section{FINDINGS AND DISCUSSION}

\subsection{Section $A$}

The first section of the questionnaire comprised the biographic information pertaining to SME manufacturers in Cape Town. The respondents were asked in which manufacturing industries their companies operated. Hence, the responses obtained from Cape Town are Agriculture (7\%), Automotive (1\%), Clothing (80\%), Consumer goods and services (1\%), Food and beverages (7\%), Printing and publishing (1\%), and Other (3\%). The respondents were asked to indicate if their respective businesses are regarded as SMEs; 99 percent said yes and 1 percent said no. Of the participating SMEs only $23 \%$ considered themselves as part of a franchise, whereas the remaining $(77 \%)$ regard themselves as non-franchise. These enterprises have at least 1 branch to a maximum of 25 branches and average 1.63 branches around Cape Town. These SMEs have been in existence for 1-2 years (20\%), 3-5 years (28\%), 6-8 years (18\%), 9-10 years (14\%) and more than 10 years (20\%). The answers were gleaned from owner ( $20 \%$ of respondents), manager (51\% of respondents), owner and manager ( $20 \%$ of respondents), and other ( $8 \%$ of respondents). Respondents were also asked to indicate if they understand the risk that may negatively affect their respective business, $88 \%$ answered yes and $12 \%$ said no. The above discussion is illustrated in Table 3 below. 
Table 3. Biographic information of SMEs manufacturing enterprises

Source: field work.

\begin{tabular}{|c|c|c|c|c|c|}
\hline \multicolumn{2}{|c|}{ Biographic information } & Frequency & Percent & Valid percent & $\begin{array}{c}\text { Cumulative } \\
\text { percent }\end{array}$ \\
\hline \multicolumn{6}{|c|}{ 3.1 What industry do you operate in? } \\
\hline \multirow{8}{*}{ Valid } & Agriculture & 6 & 6.5 & 6.5 & 6.5 \\
\hline & Automotive & 1 & 1.1 & 1.1 & 7.6 \\
\hline & Clothing & 74 & 80.4 & 80.4 & 88.0 \\
\hline & $\begin{array}{l}\text { Consumer goods \& } \\
\text { services }\end{array}$ & 1 & 1.1 & 1.1 & 89.1 \\
\hline & Food \& beverages & 6 & 6.5 & 6.5 & 95.7 \\
\hline & Printing \& publishing & 1 & 1.1 & 1.1 & 96.7 \\
\hline & Other & 3 & 3.3 & 3.3 & 100.0 \\
\hline & Total & 92 & 100.0 & 100.0 & - \\
\hline \multicolumn{6}{|c|}{ 3.2 Are you operating a franchise? } \\
\hline \multirow{3}{*}{ Valid } & Yes & 17 & 18.5 & 23.0 & 23.0 \\
\hline & No & 57 & 62.0 & 77.0 & 100.0 \\
\hline & Total & 74 & 80.4 & 100.0 & - \\
\hline Missing & System & 18 & 19.6 & - & - \\
\hline Total & & 92 & 100.0 & - & - \\
\hline \multicolumn{6}{|c|}{ 3.3 Is your business regarded as SME? } \\
\hline \multirow{3}{*}{ Valid } & Yes & 73 & 79.3 & 98.6 & 98.6 \\
\hline & No & 1 & 1.1 & 1.4 & 100.0 \\
\hline & Total & 74 & 80.4 & 100.0 & $-\ldots$ \\
\hline Missing & System & 18 & 19.6 & - & - \\
\hline Total & & 92 & 100.0 & - & - \\
\hline \multicolumn{6}{|c|}{ 3.4 How many branches do you have in Cape Town? } \\
\hline \multirow{7}{*}{ Valid } & 1 & 60 & 65.2 & 82.2 & 82.2 \\
\hline & 2 & 5 & 5.4 & 6.8 & 89.0 \\
\hline & 3 & 5 & 5.4 & 6.8 & 95.9 \\
\hline & 4 & 1 & 1.1 & 1.4 & 97.3 \\
\hline & 5 & 1 & 1.1 & 1.4 & 98.6 \\
\hline & 25 & 1 & 1.1 & 1.4 & 100.0 \\
\hline & Total & 73 & 79.3 & 100.0 & - \\
\hline Missing & System & 19 & 20.7 & - & - \\
\hline \multicolumn{2}{|l|}{ Total } & 92 & 100.0 & - & - \\
\hline \multicolumn{6}{|c|}{ 3.5 How long has your business been in existence (years)? } \\
\hline \multirow{6}{*}{ Valid } & $1-3$ years & 15 & 16.3 & 20.3 & 20.3 \\
\hline & $3-5$ years & 21 & 22.8 & 28.4 & 48.6 \\
\hline & $6-8$ years & 13 & 14.1 & 17.6 & 66.2 \\
\hline & $9-10$ years & 10 & 10.9 & 13.5 & 79.7 \\
\hline & More than 10 years & 15 & 16.3 & 20.3 & 100.0 \\
\hline & Total & 74 & 80.4 & 100.0 & - \\
\hline Missing & System & 18 & 19.6 & - & - \\
\hline \multicolumn{2}{|l|}{ Total } & 92 & 100.0 & - & - \\
\hline \multicolumn{6}{|c|}{ 3.6 What is your position in the company? } \\
\hline \multirow{5}{*}{ Valid } & Owner & 15 & 16.3 & 20.3 & 20.3 \\
\hline & Manager & 38 & 41.3 & 51.4 & 71.6 \\
\hline & Owner manager & 15 & 16.3 & 20.3 & 91.9 \\
\hline & Other & 6 & 6.5 & 8.1 & 100.0 \\
\hline & Total & 74 & 80.4 & 100.0 & - \\
\hline Missing & System & 18 & 19.6 & - & - \\
\hline \multicolumn{2}{|l|}{ Total } & 92 & 100.0 & - & - \\
\hline
\end{tabular}




\subsection{Section $B$}

Section B of the questionnaire consists of questions that relate to perception of SMEs about risk management.

According to the perceptions of the respondents, it can be noted that the majority of the respondents are familiar with risk management in their business, which draws from the fact that (51\%) of the respondents are managers and they should be familiar with risk management in their businesses (please refer to Table 4, point 4.1). We draw the conclusion that the manufacturing industry is aware that risk management initiatives play a vital role in the industry and its supply chain. This further compliments the statement by Schultz (2001) that owners managers in SMEs need to be conversant with risk identification and analysis to manage risks from a diverse range of sources.

The importance of risk management in SME manufacturing industries towards the achievement of their targeted objectives is valued, as 87 percent of respondents find risk management useful (please see Table 4, point 4.2). This finding supports Smit and Watkins (2012) when they state that SMEs that incorporate risk management are better equipped to exploit resources pertaining to their organizations. This is also in line with the Gupta's (2011) findings that managers had an understanding and a perception that effective risk management improves organizational performance.

From Table 4 (point 4.3), it is noted that the majority of the respondents are risk proactive by $(73 \%)$, which draws from the fact that 88 percent of the respondents understand the risk that may negatively affect their business. This response entails that respondents understand the main outcome of risk management is to reduce the number of threats that materialize into problems and to minimize the effect of those which do occur (Hillson, 2009).

In Table 4 (point 4.4), it is evident that the majority of the respondents file their risk, but (39\%) don't file their risk or partly do so. This is a major concern considering the life span of SMEs. These findings concur with Napp (2011) to some extent when he mentions that risk occurrence can be a danger to SME continuity. It is of importance that SMEs focus and try to implement comprehensive risk management.

According to the perceptions of the respondents, as shown in Table 4 (point 4.5), it can be noted that less than the majority (54\%) budgeted for controls used to identify and mitigate risk. 56 percent of the respondents don't budget. This is a major concern when one considers that the failure rate of these businesses within their first three years of existence is very high (Fatoki \& Smit, 2011; Fatoki, 2012; Ngary et al., 2014). This could affect normal operations and profitability of business.

From Table 4, (point 4.6), it can be established that 49 percent of controls are reactively expensed, while 51 percent is not. This finding is quite concerning considering that SMEs are often considered as the backbone of the economy and main driver of economic growth in the country (Joubert et al., 1999; Apulu et al., 2011; Tehseen \& Ramayah, 2015).

From Table 4 (point 4.7), it can be established that one of the reasons for poor risk management is that only $50 \%$ of managers or owners communicate risk and controls to their employees; furthermore, no adequate training is provided on risk management initiatives. This explains why the failure rate of SMEs is so high. One of the contributing factors affecting SMEs is the low levels of education and training, poor business skills and poor business efficiencies among SMEs (Yanta, 2001).

Table 4 (point 4.8) also provides evidence for one to conclude that owners and managers regard risk management as a top priority for the success of their business by 74 percent. This is a good sign for the future, if managers regard managing risk effectively to become paramount to the success rate of SMEs. This means business leaders understand the statement made by Aruwa (2005) that risk management is simply protecting the business from possible negative occurrences, as well as recognizing opportunities and capitalising on them when they arise.

From the above Table 4 (point 4.9), it is evident that majority of respondents address risk timeously after identifying them and only $26 \%$ do not, 
Table 4. Perceptions on risk management

Source: field work.

\begin{tabular}{cc|c|c|c|c}
\hline $\begin{array}{c}\text { Perceptions on risk } \\
\text { management }\end{array}$ & Frequency & Percent & Valid Percent & $\begin{array}{c}\text { Cumulative } \\
\text { Percent }\end{array}$ \\
\hline & & 4.1 & Are you familiar with risk management in your business? & \\
\hline & Yes & 63 & 68.5 & 85.1 & 85.1 \\
Valid & No & 6 & 6.5 & 8.1 & 93.2 \\
& Partly & 5 & 5.4 & 6.8 & 100.0 \\
& Total & 74 & 80.4 & 100.0 & - \\
\hline Missing & System & 18 & 19.6 & - & - \\
\hline Total & & 92 & 100.0 & - & - \\
\hline
\end{tabular}

4.2 Do you consider risk management to be useful for your company?

\begin{tabular}{|c|c|c|c|c|c|}
\hline \multirow{4}{*}{ Valid } & Yes & 64 & 69.6 & 86.5 & 86.5 \\
\hline & No & 6 & 6.5 & 8.1 & 94.6 \\
\hline & Partly & 4 & 4.3 & 5.4 & 100.0 \\
\hline & Total & 74 & 80.4 & 100.0 & - \\
\hline Missing & System & 18 & 19.6 & - & - \\
\hline \multicolumn{2}{|l|}{ Total } & 92 & 100.0 & - & - \\
\hline \multicolumn{6}{|c|}{ 4.3 Do you manage risk proactively? } \\
\hline \multirow{4}{*}{ Valid } & Yes & 54 & 58.7 & 73.0 & 73.0 \\
\hline & No & 8 & 8.7 & 10.8 & 83.8 \\
\hline & Partly & 12 & 13.0 & 16.2 & 100.0 \\
\hline & Total & 74 & 80.4 & 100.0 & - \\
\hline Missing & System & 18 & 19.6 & - & - \\
\hline \multicolumn{2}{|l|}{ Total } & 92 & 100.0 & - & - \\
\hline
\end{tabular}

\begin{tabular}{|c|c|c|c|c|c|}
\hline \multicolumn{6}{|c|}{ 4.4 Are risk facing organization logged and filed? } \\
\hline \multirow{4}{*}{ Valid } & Yes & 45 & 48.9 & 60.8 & 60.8 \\
\hline & No & 14 & 15.2 & 18.9 & 79.7 \\
\hline & Partly & 15 & 16.3 & 20.3 & 100.0 \\
\hline & Total & 74 & 80.4 & 100.0 & - \\
\hline Missing & System & 18 & 19.6 & - & - \\
\hline \multicolumn{2}{|l|}{ Total } & 92 & 100.0 & - & - \\
\hline
\end{tabular}

\begin{tabular}{|c|c|c|c|c|c|}
\hline \multicolumn{6}{|c|}{ 4.5 Are controls to identify risk proactively budgeted for? } \\
\hline \multirow{4}{*}{ Valid } & Yes & 40 & 43.5 & 54.1 & 54.1 \\
\hline & No & 12 & 13.0 & 16.2 & 70.3 \\
\hline & Partly & 22 & 23.9 & 29.7 & 100.0 \\
\hline & Total & 74 & 80.4 & 100.0 & $-\ldots$ \\
\hline Missing & System & 18 & 19.6 & - & - \\
\hline \multicolumn{2}{|l|}{ Total } & 92 & 100.0 & - & - \\
\hline \multicolumn{6}{|c|}{ 4.6 Are controls to identify risk reactively expensed? } \\
\hline \multirow{4}{*}{ Valid } & Yes & 36 & 39.1 & 48.6 & 48.6 \\
\hline & No & 18 & 19.6 & 24.3 & 73.0 \\
\hline & Partly & 20 & 21.7 & 27.0 & 100.0 \\
\hline & Total & 74 & 80.4 & 100.0 & \\
\hline Missing & System & 18 & 19.6 & & \\
\hline \multicolumn{2}{|l|}{ Total } & 92 & 100.0 & & \\
\hline \multicolumn{6}{|c|}{ 4.7 Are risk and controls communicated to all employees? } \\
\hline \multirow{4}{*}{ Valid } & Yes & 37 & 40.2 & 50.0 & 50.0 \\
\hline & No & 15 & 16.3 & 20.3 & 70.3 \\
\hline & Partly & 22 & 23.9 & 29.7 & 100.0 \\
\hline & Total & 74 & 80.4 & 100.0 & - \\
\hline Missing & System & 18 & 19.6 & - & - \\
\hline \multicolumn{2}{|l|}{ Total } & 92 & 100.0 & - & - \\
\hline
\end{tabular}


Table 4 (cont). Perceptions on risk management

\begin{tabular}{|c|c|c|c|c|c|}
\hline \multicolumn{2}{|c|}{$\begin{array}{c}\text { Perceptions on risk } \\
\text { management }\end{array}$} & Frequency & Percent & Valid Percent & $\begin{array}{c}\text { Cumulative } \\
\text { Percent }\end{array}$ \\
\hline \multicolumn{6}{|c|}{ 4.8 Does risks form part of the agenda in leadership meetings? } \\
\hline \multirow{4}{*}{ Valid } & Yes & 55 & 59.8 & 74.3 & 74.3 \\
\hline & No & 7 & 7.6 & 9.5 & 83.8 \\
\hline & Partly & 12 & 13.0 & 16.2 & 100.0 \\
\hline & Total & 74 & 80.4 & 100.0 & - \\
\hline Missing & System & 18 & 19.6 & - & - \\
\hline \multicolumn{2}{|l|}{ Total } & 92 & 100.0 & - & - \\
\hline \multicolumn{6}{|c|}{ 4.9 Are risks addressed within a reasonable time after identification? } \\
\hline \multirow{4}{*}{ Valid } & Yes & 55 & 59.8 & 74.3 & 74.3 \\
\hline & No & 8 & 8.7 & 10.8 & 85.1 \\
\hline & Partly & 11 & 12.0 & 14.9 & 100.0 \\
\hline & Total & 74 & 80.4 & 100.0 & - \\
\hline Missing & System & 18 & 19.6 & - & - \\
\hline \multicolumn{2}{|l|}{ Total } & 92 & 100.0 & - & - \\
\hline \multicolumn{6}{|c|}{ 4.10 Are there effective risk communication channels from the bottom level up for emerging risks? } \\
\hline \multirow{4}{*}{ Valid } & Yes & 44 & 47.8 & 59.5 & 59.5 \\
\hline & No & 11 & 12.0 & 14.9 & 74.3 \\
\hline & Partly & 19 & 20.7 & 25.7 & 100.0 \\
\hline & Total & 74 & 80.4 & 100.0 & - \\
\hline Missing & System & 18 & 19.6 & - & - \\
\hline \multicolumn{2}{|l|}{ Total } & 92 & 100.0 & - & - \\
\hline \multicolumn{6}{|c|}{4.11 Is the cost of employing risk management initiatives justified in comparison to the benefit? } \\
\hline \multirow{4}{*}{ Valid } & Yes & 40 & 43.5 & 54.1 & 54.1 \\
\hline & No & 14 & 15.2 & 18.9 & 73.0 \\
\hline & Partly & 20 & 21.7 & 27.0 & 100.0 \\
\hline & Total & 74 & 80.4 & 100.0 & - \\
\hline Missing & System & 18 & 19.6 & $-\ldots$ & - \\
\hline \multicolumn{2}{|l|}{ Total } & 92 & 100.0 & - & - \\
\hline \multicolumn{6}{|c|}{ 4.12 Do you know where to get information about risk management and which specialists to contact? } \\
\hline \multirow{4}{*}{ Valid } & 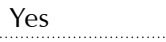 & 57 & 62.0 & 77.0 & 77.0 \\
\hline & No & 11 & 12.0 & 14.9 & 91.9 \\
\hline & Partly & 6 & 6.5 & 8.1 & 100.0 \\
\hline & Total & 74 & 80.4 & 100.0 & - \\
\hline Missing & System & 18 & 19.6 & - & - \\
\hline \multicolumn{2}{|l|}{ Total } & 92 & 100.0 & - & - \\
\hline
\end{tabular}

which is acceptable considering that $56 \%$ of the respondents do not budget for controls used to mitigate and identify risk. This is a good sign although not convincing enough and, therefore, managers have to promptly evaluate risk associated with their organizations as SMEs are regarded as being 'risky' because of their escalating non-success rate (Terungwa, 2012; Ahmmed \& Bown, 2016).

From Table 4 (point 4.10), the researchers' note that majority of 59 percent of the respondents indicated that there is effective communication channels in place, 15 percent did not agree to statement, while 26 percent were not sure. This is a concern to the researchers as lack of entre- preneurial knowledge and business management skills is often credited as one of SMEs major failures (Scarborough \& Zimmerer, 1996). Again communication needs to be improvised in order to build the risk appetite (Gupta, 2011) across all levels with the organization.

From Table 4 (point 4.11), one can establish from the respondents that majority of the respondents feel that the cost of employing risk management initiatives outweighs the benefits, ultimately negatively affecting their profitability. According to the perceptions of the respondents in Table 4 (point 4.12), it can be noted that the majority of $77 \%$ know where to get risk management informa- 
tion and specialist to contact, which embraces the fact that 74 percent of the respondents include risk management in their agenda for leadership meetings. In order to become more competitive and efficient SMEs in the manufacturing sector need to formalize (enhance) their internal structures and systems (Terziovski, 2010).

\subsection{Section C}

This section discusses results pertaining to risk management practices of SMEs in the manufacturing sector.

From Table 5 (point 5.2), it is established that 87 percent of businesses include principles of risk management in their policy and 13 percent do not, this is quite alarming considering the importance of risk management in the sustainability of SMEs and the high failure rate of SMEs. One of the factors hindering progress of small businesses is that business leaders are not able to identify all the risk elements that have impact on their business activities (Smit \& Watkins, 2012).

From Table 5 (point 5.3), it is noted that the majority of the respondents indicate that 74 percent of management clearly support risk management. This supports the finding in Table 5 (point 5.1) of the importance of risk management activities to the respondents. The latter also support our literature review discussion that if risk management can be managed effectively and efficiently, it can help businesses become more cost-effective and sustainable.

Table 5. Risk management practices of SMEs in the manufacturing sector

Source: field work.

\begin{tabular}{|c|c|c|c|c|c|}
\hline \multicolumn{2}{|c|}{ Risk management practices } & Frequency & Percent & Valid Percent & $\begin{array}{c}\text { Cumulative } \\
\text { Percent }\end{array}$ \\
\hline \multicolumn{6}{|c|}{ 5.1 Risk management initiatives are considered important in the manufacturing industry } \\
\hline \multirow{5}{*}{ Valid } & Strongly agree & 52 & 56.5 & 70.3 & 70.3 \\
\hline & Agree & 10 & 10.9 & 13.5 & 83.8 \\
\hline & Disagree & 9 & 9.8 & 12.2 & 95.9 \\
\hline & Strongly disagre e & 3 & 3.3 & 4.1 & 100.0 \\
\hline & Total & 74 & 80.4 & 100.0 & - \\
\hline Missing & System & 18 & 19.6 & - & - \\
\hline \multicolumn{2}{|l|}{ Total } & 92 & 100.0 & - & - \\
\hline \multicolumn{6}{|c|}{ 5.2 The general principles of risk management are included in our operational policy } \\
\hline \multirow{5}{*}{ Valid } & Strongly agree & 42 & 45.7 & 56.8 & 56.8 \\
\hline & Agree & 22 & 23.9 & 29.7 & 86.5 \\
\hline & Disagree & 9 & 9.8 & 12.2 & 98.6 \\
\hline & Strongly disagree & 1 & 1.1 & 1.4 & 100.0 \\
\hline & Total & 74 & 80.4 & 100.0 & - \\
\hline Missing & System & 18 & 19.6 & - & - \\
\hline \multicolumn{2}{|l|}{ Total } & 92 & 100.0 & - & - \\
\hline \multicolumn{6}{|c|}{5.3 Risk management is clearly supported by management } \\
\hline \multirow{5}{*}{ Valid } & Strongly agree & 40 & 43.5 & 54.1 & 54.1 \\
\hline & Agree & 15 & 16.3 & 20.3 & 74.3 \\
\hline & Disagree & 11 & 12.0 & 14.9 & 89.2 \\
\hline & Strongly disagree & 8 & 8.7 & 10.8 & 100.0 \\
\hline & Total & 74 & 80.4 & 100.0 & - \\
\hline Missing & System & 18 & 19.6 & - & - \\
\hline \multicolumn{2}{|r|}{ 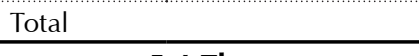 } & 92 & 100.0 & - & - \\
\hline \multicolumn{6}{|c|}{$\begin{array}{l}\text { 5.4 The management personnel identify, analyses and adequately respond to risks affecting } \\
\text { the organization on a regular basis }\end{array}$} \\
\hline \multirow{5}{*}{ Valid } & Strongly agree & 26 & 28.3 & 35.1 & 35.1 \\
\hline & Agree & 16 & 17.4 & 21.6 & 56.8 \\
\hline & Disagree & 29 & 31.5 & 39.2 & 95.9 \\
\hline & Strongly disagree & 3 & 3.3 & 4.1 & 100.0 \\
\hline & Total & 74 & 80.4 & 100.0 & - \\
\hline Missing & System & 18 & 19.6 & - & - \\
\hline \multicolumn{2}{|l|}{ Total } & 92 & 100.0 & - & - \\
\hline
\end{tabular}


Table 5 (cont). Risk management practices of SMEs in the manufacturing sector

\begin{tabular}{|c|c|c|c|c|c|}
\hline \multicolumn{2}{|c|}{ Risk management practices } & Frequency & Percent & Valid Percent & $\begin{array}{c}\text { Cumulative } \\
\text { Percent }\end{array}$ \\
\hline \multicolumn{6}{|c|}{$\begin{array}{l}\text { 5.5 Adequate knowledge, proper training and advanced technology } \\
\text { are considered in risk management processes }\end{array}$} \\
\hline \multirow{5}{*}{ Valid } & Strongly agree & 26 & 28.3 & 35.1 & 35.1 \\
\hline & Agree & 31 & 33.7 & 41.9 & 77.0 \\
\hline & Disagree & 13 & 14.1 & 17.6 & 94.6 \\
\hline & Strongly disagree & 4 & 4.3 & 5.4 & 100.0 \\
\hline & Total & 74 & 80.4 & 100.0 & - \\
\hline Missing & System & 18 & 19.6 & $-\ldots$ & - \\
\hline \multicolumn{2}{|l|}{ Total } & 92 & 100.0 & - & - \\
\hline \multicolumn{6}{|c|}{ 5.6 Risk management tasks and roles are clearly assigned } \\
\hline \multirow{5}{*}{ Valid } & Strongly agree & 19 & 20.7 & 25.7 & 25.7 \\
\hline & Agree & 38 & 41.3 & 51.4 & 77.0 \\
\hline & Disagree & 14 & 15.2 & 18.9 & 95.9 \\
\hline & Strongly disagree & 3 & 3.3 & 4.1 & 100.0 \\
\hline & Total & 74 & 80.4 & 100.0 & - \\
\hline Missing & System & 18 & 19.6 & - & - \\
\hline \multicolumn{2}{|l|}{ Total } & 92 & 100.0 & - & - \\
\hline \multicolumn{6}{|c|}{ 5.7 Risk management is monitored and reported as part of our normal management reporting system } \\
\hline \multirow{5}{*}{ Valid } & Strongly agree & 24 & 26.1 & 32.4 & 32.4 \\
\hline & Agree & 30 & 32.6 & 40.5 & 73.0 \\
\hline & Disagree & 11 & 12.0 & 14.9 & 87.8 \\
\hline & Strongly disagree & 9 & 9.8 & 12.2 & 100.0 \\
\hline & 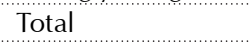 & 74 & 80.4 & 100.0 & $-\ldots$ \\
\hline Missing & System & 18 & 19.6 & $-\ldots$ & - \\
\hline \multicolumn{2}{|l|}{ Total } & 92 & 100.0 & - & - \\
\hline \multicolumn{6}{|c|}{ 5.8 We use risk analysis methods that are recommended by specialists } \\
\hline \multirow{5}{*}{ Valid } & Strongly agree & 27 & 29.3 & 36.5 & 36.5 \\
\hline & Agree & 25 & 27.2 & 33.8 & 70.3 \\
\hline & Disagree & 18 & 19.6 & 24.3 & 94.6 \\
\hline & Strongly disagree & 4 & 4.3 & 5.4 & 100.0 \\
\hline & Total & 74 & 80.4 & 100.0 & - \\
\hline Missing & System & 18 & 19.6 & - & - \\
\hline \multicolumn{2}{|l|}{ Total } & 92 & 100.0 & - & - \\
\hline \multicolumn{6}{|c|}{$\begin{array}{c}\text { 5.9 When analyzing significant risks, we use in-depth risk analysis methods, and our methods } \\
\text { of working are modified to minimize the level of risk }\end{array}$} \\
\hline \multirow{5}{*}{ Valid } & Strongly agree & 21 & 22.8 & 28.4 & 28.4 \\
\hline & Agree & 32 & 34.8 & 43.2 & 71.6 \\
\hline & Disagree & 15 & 16.3 & 20.3 & 91.9 \\
\hline & Strongly disagree & 6 & 6.5 & 8.1 & 100.0 \\
\hline & Total & 74 & 80.4 & 100.0 & - \\
\hline Missing & System & 18 & 19.6 & - & - \\
\hline \multicolumn{2}{|l|}{ Total } & 92 & 100.0 & - & - \\
\hline \multicolumn{6}{|c|}{ 5.10 Employees have the skill to participate in the development of risk management activities } \\
\hline \multirow{5}{*}{ Valid } & Strongly agree & 19 & 20.7 & 25.7 & 25.7 \\
\hline & 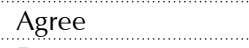 & 31 & 33.7 & 41.9 & 67.6 \\
\hline & Disagree & 14 & 15.2 & 18.9 & 86.5 \\
\hline & Strongly disagree & 10 & 10.9 & 13.5 & 100.0 \\
\hline & Total & 74 & 80.4 & 100.0 & \\
\hline Missing & System & 18 & 19.6 & & \\
\hline Total & & 92 & 100.0 & & \\
\hline & 11 Employees part & $\begin{array}{r}\text { in risk mar } \\
\text { of the }\end{array}$ & $\begin{array}{l}\text { activities } \\
\text { pecific tas }\end{array}$ & side and outsic & scope \\
\hline & Strongly agree & 25 & 27.2 & 33.8 & 33.8 \\
\hline & Agree & 24 & 26.1 & 32.4 & 66.2 \\
\hline Valid & Disagree & 14 & 15.2 & 18.9 & 85.1 \\
\hline & Strongly disagree & 11 & 12.0 & 14.9 & 100.0 \\
\hline & Total & 74 & 80.4 & 100.0 & - \\
\hline Missing & System & 18 & 19.6 & - & - \\
\hline Total & & 92 & 100.0 & - & - \\
\hline
\end{tabular}


From Table 5 (point 5.4), it is evident that the majority of respondents (57\%) agree that management personnel identify, analyze and adequately respond to risk affecting the organization on a regular basis. Forty-three percent of the respondents who disagree are quite alarming considering that 74 percent of management clearly supports risk management. Failure to practice risk management, may lead to appalling consequences for SMEs (Smit, 2012).

According to the perceptions of the respondents, it can be noted from Table 5 (point 5.5) that the majority of 77 percent agree that training is essential to employees understanding the importance of risk management. This finding gives hope to the improvement of Table 5 (point 5.7) that $50 \%$ of respondents indicated that risk management initiatives are not communicated to employees and no adequate training is provided to employees. This finding further strengthens Urban and Naidoo (2012) statement that skills upgrade should be prioritized among SMEs. This necessitates the need for risk management training, as Gupta (2011) notes that managers are unclear on how to document risk management activities within their organizations.

From Table 5 (point 5.6), 77 percent of the respondents acknowledge the assignment of roles as one of the factors of having a good risk management. This shows good management skills which are contrary to the statement made by Everett and Watson (1998) that SMEs manager and owners lack business management skills.

Table 5 (point 5.7) below indicates that risk management is really a top priority for management team, with strong response of 73 percent which agrees. This finding is in line with the results on Table 5 (point 5.8), which stipulates that 74 percent of the managers and owners include risk management in their agenda for leadership meetings. This is a good response, since banks consider SMEs very risky because of their high failure rate (Terungwa, 2012; Ahmmed \& Bown, 2016). Therefore this might be a turnaround strategy for success of SMEs particularly in the manufacturing sector.
From Table 5 (point 5.8), it is evident that the majority of respondents (70.3\%) use risk analysis methods recommended by specialists. The 30 percent of the respondents are quite concerned facing the industry, considering that 88 percent of the respondents indicated that they do understand the risk which may negatively affect their organizations.

From Table 5 (point 5.9) above, it is noted that the majority of the respondents (72\%) use in-depth risk analysis methods, and their methods are modified to minimize the level of risk. This finding is contrary to the statement made by Noorvee (2006) that business leaders do not identify imminent risks faced by small businesses due to the lack of proper internal controls and assurance activities (Prinsloo et al., 2015). The concern is the 28 percent who do not use in-depth risk analysis, whilst $74 \%$ of management strongly support risk management. This further becomes more concerning if you take into account that the manufacturing enterprises play a significant and crucial role in economic growth and the sustainable development of any economy (Abor \& Quartey, 2010; Kongolo, 2010; Apulu et al., 2011).

From Table 5 (point 5.10), it is evident that the majority of respondents (68\%) believe that their employees have the skill to participate in the development of risk management. The concern within this finding is that $32 \%$ believe otherwise. This observation supports that lack of business knowledge and adequate skills among SME manufacturers, which is one of the sources of business failure (El Namaki, 1990; Scarborough \& Zimmerer, 1996; Everette \& Watson, 1998; Olawale \& Garwe, 2010).

According to the respondents, it can be noted from Table 5.11 that the majority (66\%) agree that employees participate in risk management activities, both inside and outside the scope of their own specific task. It is unacceptable that $34 \%$ of respondents disagreed. This is also a challenge while taking into cognizance that a huge percentage of SMEs is estimated to fail within their first few years of operation (Van Eeden et al., 2003; Cant \& Wiid, 2013). 


\section{CONCLUSION}

The purpose of this study was to describe risk management practices of SMEs in the manufacturing sector. A positivist research paradigm was adopted and a quantitative research approach was used through the use of questionnaires to collect data from SME manufacturers in Cape Town. Even though from the above results there are some seemingly positive statistics, nonetheless, these statistics are only helping in masking the true deficiencies behind the use of risk management initiatives. From the above analysis, it is evident that SME owners and managers in the manufacturing industry need to be educated regarding risk management initiatives, although the majority of them are aware of the risk that may negatively affect their organizations. Most of the respondents indicated that risk management is strongly supported by management, and forms part of their agenda in leadership meetings. This indicates that although owner and managers of small businesses understand risk management; however, they do not know how to utilize risk management initiatives effectively to benefit their organizations. The respondents do not make adequate use of the formal risk management initiatives at their disposal. This is one of the reasons the profitability and sustainability of SMEs is a major problem. It is felt that the emphasis should be to increase the knowledge of risk management to employees, as the above average of the respondents indicated that risk and controls are not communicated to all employees, and that not enough training is given to employees on risk management.

Based on the literature review and findings above, it is clear that SMEs have not mastered the use of risk management initiatives to a greater extent, thereby putting their businesses at risk towards achieving their objectives in the long run. These challenges can be addressed if all-risk champions work together from a one-risk universe and combine their efforts in a synchronized fashion to risk management.

\section{Practical implications and suggestions for further research}

With regard to the risks involved in SME manufactures, it is suggested that companies should be more concerned with whether employees are aware of risk management initiatives and how they can mitigate and control risks to improve the sustainability and profitability of SMEs. Companies that do not understand risk management should outsource a risk management service to mitigate the risks facing the manufacturing businesses. Furthermore, it is recommended that organisations should promote their risk management initiatives so that employees have a clear and better understanding of the risk management activities in the organization in dealing with emerging risks that may negatively affect the achievement of targeted objectives. All employees, managers and owners must coordinate their efforts to identify and manage organizational risks within their ambit to obtain total risk coverage, as well as provide the assurance that these risks are effectively managed from a coordinated approach. Further studies may be carried out to identify measures that can be taken to improve the effectiveness of risk management initiatives in SMEs. Further studies may be explored on the risk management practices in the supply-chain management of SME manufacturing enterprises, since this study only focuses on the internal risk management initiatives and not the entire value chain.

\section{REFERENCES}

1. Abor, J., \& Quartey, P. (2010). Issues in SME Development in Ghana and South Africa. International Research Journal of Finance and Economics, 39(1), 218-228.

2. Ahmmed, K., \& Bown, R. (2016). Exploring the Role of Private Commercial Banks in
Increasing Small and Medium Size Enterprises' Financial Accessibility in Developing Countries: A Study in Bangladesh. World Academy of Science, Engineering and Technology International Journal of Social, Behavioral, Educational, Economic, Business and Industrial Engineering, 10(6), 2105-2116.
3. Apulu, I., Lathen, A., \& Moreton, R. (2011). Factors affecting the effective utilization and adoption of sophisticated ICT solutions: Case studies of SMEs in Lagos, Nigeria. Journal of Systems and Information Technology, 13(2), 125-143. 
4. Aruwa, S.A.S. (2005). The Business Entrepreneur: A Guide to Entrepreneurial Development. Kaduna: Scopy Publishing.

5. Barry, J. (2004). Supply chain risk in an uncertain global supply chain environment. International Journal of Physical Distribution and Logistics Management, 34(9), 695-697.

6. Beasly, M., Chen, A., Nune, K., \& Wright, L. (2006). Working hand in hand; Balance Scorecard and Enterprise Risk Management. Strategic Finance, 87(9), 180-206.

7. Betchoo, N. K. (2015). The need for accounting training Packages for small scale firms in rural Mauritius. Advances in Social Sciences Research Journal, 2(7), 15-26.

8. Bolton, P. (2006). Government Procurement as a Policy Tool in South Africa. Journal of Public Procurement, 6(3), 193-217.

9. Bryman, A., Bell, E., Hirschsohn, P., dos Santos, A., Du Toit, J., Masenge, A., Van Aardt, I., \& Wagner, C. (2014). Research Methodology: Business and Management Contexts. Cape Town: Oxford University Press.

10. Butcher, C. (1999). DTI positioning South Africa for global competitiveness. Institute of Marketing Management. Professional Marketing Review, 1-15.

11. Cant, M. C., \& Wiid, J. A. (2013). Establishing the Challenges Affecting South African SMEs. International Business \& Economics Research Journal, 12(6), 707-716.

12. Ching, H. Y., \& Colombo, T. M. (2014). Enterprise Risk Management Good Practices and Proposal of Conceptual Framework. Journal of Management Research, 6(3), 69-85.

13. Committee of Sponsoring Organizations of the Treadway Commission (COSO). (2004). Enterprise Risk Management Integrated Framework Executive Summary. Retrieved from http/:www.coso.org/documents/ coso_erm_executivesummary.pdf (accessed on 10.03.2015).
14. Davies, T. A. (2001). Enhancing competitiveness in the manufacturing sector: key opportunities provided by inter firm clustering. Competitiveness Review, 11(2), 4-12.

15. Davis, C. (2014). The aims of research. A chapter in Research Matters. In du Plooy - Cilliers, F., Davis, C., \& Bezuidenhout, R. (Eds.), 1-17, 74-81. Lansdowne, Cape Town: Juta.

16. De Bakker, K., Boonstra, A., \& Wortmann, H. (2010). Does risk management contribute to IT project success? A meta-analysis of empirical evidence. International Journal of Project Management, 28, 493-503.

17. Ekwere, N. (2016). Framework of effective risk management in Small and Medium Enterprises (SMES): A literature review. Journal. Unpar. Ac.id, 20(1), 23-46.

18. El-Namaki, M. S. S. (1990). Small business: the myths and the reality. Long Range Planning, 23(4), 78-87.

19. Everett, J., \& Watson, J. (1998). Small Business Failure and External Risk Factors. Small Business Economics, 11(4), 371-390.

20. Faisal, M. N., Banwet, D. K., \& Shankar, R. (2007). Information risks management in supply chains: an assessment and mitigation framework. Journal of Enterprise Information Management, 20(6), 677-699.

21. Fatoki, O. (2012). An Investigation into the Financial Management Practices of New Micro-enterprises in South Africa. Journal of Social Science, 33(2), 179-188.

22. Fatoki, O., \& Smit, A. (2011). Constraints to credit access by new SMEs in South Africa: A supply-side analysis. African Journal of Business Management, 5(4), 1413-1425.

23. Finch, P. (2004). Supply chain risk management. Supply Chain Management: An International Journal, 9(2), 183-196.

24. Gupta, P. K. (2011). Risk management in Indian companies: EWRM concerns and issues. The Journal of Risk Finance, 12(2), 121-139.
25. Harland, C., Brenchley, R., \& Walker, H. (2003). Risk in supply networks. Journal of Purchasing and Supply Management, 9(1), 51-62.

26. Hillson, D. (2009). Managing Risk in Projects. England: Burlington.

27. Hsu, C., Lien, Y., \& Chen, H. (2013). International ambidexterity and firm performance in small emerging economies. Journal of World Business, 48(1), 58-67.

28. Jackson, S. L. (2009). Research Methods and Statistics: A critical thinking Approach. USA: Wadsworth.

29. Joubert, C., Schoeman, N., \& Blignaut, J. (1999). Small, Medium and Micro Sized Enterprises (SMMEs) and the Housing Construction Industry: A Possible Solution to South Africa's Socio Economic Problems. SAJEMS NS, 2(1), 21-33.

30. Jowah, L. (2011). Research methodology: Research is a process and hence follows a logical sequence from start to finish. Cape Town: Jowah Book publishers.

31. Kongolo, M. (2010). Job creation versus job shedding and the role of SMEs in economic development. African Journal of Business Management, 4(11), 2288-2295.

32. Koonin, M. (2014). Validity and Reliability. A chapter in Research Matters. In du Plooy- Cilliers, F., Davis, C., \& Bezuidenhout, R. (Eds.), 252-259. Lansdowne, Cape Town: Juta.

33. Kraus, S., Rigtering J.P.C., Hughes, M., \& Hosman, V. (2012).

Entrepreneurial orientation and the business performance of SMEs: a quantitative study from the Netherlands. Rev Manag Sci, 6, 161-182.

34. Lavastre, O., Gunasekaran, A., \& Spalanzani, A. (2012). Supply chain risk management in French companies. Decision Support Systems, 52, 828-838.

35. Malhotra, R., \& Temponi, C. (2010). Critical decisions for ERP integration: Small business issues. International Journal of Information Management, 30(1), 28-37. 
36. Manu, C. (2005). Risk management in the context of public sector reforms. Retrieved from http://www.modernghana. com/news/116837/1/riskmanagement-in-the-context-ofpublic-sector-re.html (accessed on 12.03.15).

37. Mbonyane, B., \& Ladzani, W. (2011). Factors that hinder the growth of small businesses in South African townships. Eur. Bus. Rev, 23(6), 550-560.

38. Minsky, S. (2012). How to measure your Enterprise Risk Management effectiveness. Retrieved from http:// www.ebizq.net/blogs/chief_risk_ officer/2012/01/how_to_measure_ your_enterprise.php (accessed on 06.04.15).

39. Napp, A. K. (2011). Financial risk management in SME - The use of financial analysis for identifying, analyzing and monitoring internal financial risks. Master thesis. Aarhus School of Business, Aarhus University.

40. National Credit Requlator (NCR). (2011). Literature Review on Small and Medium Enterprises' Access to Credit and Support in South Africa.

41. Ngary, C., Smit, Y., Bruwer, J-P., \& Ukpere, W. I. (2014). Financial Performance Measures and Business Objectives Attainment in Fast Food SMMEs in the Cape Metropolis: A preliminary Liability and Suitability analysis. Mediterranean Journal of Social Sciences, 5(20), 909-921.

42. Ngubane, N., Mayekiso, S., Sikota, S., Fitshane, S., Matsoso, M., \& Bruwer, J. P. (2015). Inventory Management Systems used by Manufacturing Small Medium and Micro Enterprises in Cape Town. Mediterranean Journal of Social Sciences, 6(1), 2039-9340.

43. Noorvee, L. (2006). Evaluation of the Effectiveness of Internal Controls over Financial Reporting. Master's Thesis, University of Tartu, Tartu.

44. Ntsika Enterprise Promotion Agency. (2001). State of Small Business Development in South Africa. Annual Review. Retrieved from http://www.transformationaudit.org.za/researchdatabase/ government1/other-governmentoutput/2000-2006/2001ntsika/ (accessed on 03.03.2015).

45. Oak Ridge Associated Universities (2005). What are performance measures? Retrieved from http:// www.orau.gov/pbm/documents/ overview/wapm.html (accessed 22.03.2015).

46. Olawale, F., \& Garwe, D. (2010). Obstacles to the Growth of New SMEs in South Africa: A Principal Component Analysis Approach. African Journal of Business Management, 4(5), 729-738.

47. Pietersen, J., \& Maree, K. (2007). Standardisation of a questionnaire. A chapter in First steps in research by Creswell, J. W., Elbersohn, L., Eloff, I., Ferreira, R., Ivankova, N. V., Jansen, J. D., Nieuwenhuis, J., Pietersen, J., Plano Clark, V.L., \& Van der Westhuizen, C. Hatfield, Pretoria: Van Schaik.

48. Prinsloo, S., Walker, C., Botha, L., Bruwer, J. P., \& Smit, Y. (2015). The Influence of Combined Assurance Initiatives on the Efficiency of Risk Management in Retail Small and Very Small Enterprises in Bellville, South Africa. Expert Journal of Business and Management, 3(2), 63-81.

49. Rao, S., \& Goldsby, T. J. (2009). Supply chain risks: a review and typology. The International Journal of Logistics Management, 20(1), 97-123.

50. Rogerson, C. M. (2013). Improving market access opportunities for urban small, medium and micro-enterprises in South Africa. Urbani izziv, 24(2), 133-143.

51. Scarborough, N. M., \& Zimmerer, T. W. (1996). Effective Small Business Management. 5th ed. Upper Saddle River, NJ: Prentice Hall.

52. Schultz, A. G. (2001). Risk assurance model for the small medium and micro enterprise sector. A dissertation submitted in partial fulfillment of the requirements for the degree of Master Technologiae in the Faculty of Management at the Cape Technikon.
53. SEDA. (2010). Small Enterprise Development Agency Monitoring. Retrieved from http://www.seda. org.za/Publications/Publications/ SEDA\%20SBM\%20Vol.6\%20 Issue\%201\%202010.pdf (accessed on 22.03.2015).

54. Senik, Z., Scott-Ladd, C., Entrekin, L., \& Adham, K. A. (2011). Networking and Internationalization for SMEs in emerging economies. J.Int Entreprenuership, 9, 259-281.

55. Singh, R., Garg, S., \& Deshmukh, S. (2010). The competitiveness of SMEs in a globalized economy: Observations from China and India. Management Research Review, 33(1), 54-65.

56. Smit, Y. (2012). A structured approach to risk management for South African SMEs. A dissertation submitted in fulfillment of the requirements for the degree of Doctor Technology in the Faculty of Business at the Cape Peninsula University of Technology.

57. Smit, Y., \& Watkins, J. (2012). A literature review of small and medium (SME) risk management practices in South Africa enterprises. African Journal of Business Management, 6(21), 6324-6330.

58. South Africa. (1996). National Small Business Enabling Act No, 102 of 1996. Pretoria: Government Printer.

59. Statistics South Africa. (2011). Mid-year population estimates. Retrieved from http://www. statssa.gov.za/publications/P0302/ P03022011.pdf (accessed on 03.04.2015)

60. Tang, C. S. (2006). Perspectives in supply chain risk management. International Journal of Production Economics, 103, 451-488.

61. Tang, O. U., \& Musa, S. N. (2011). Identifying risk issues and research advancements in supply chain risk management. Int. J. Production Economics, 133, 25-34.

62. Tehseen, S., \& Ramayah, T. (2015). Entrepreneurial Competencies and SMEs Business Success: The Contingent Role of External 
Integration. Mediterranean Journal of Social Sciences, 6(1), 50-61.

63. Terungwa, A. (2012). Risk Management and Insurance of Small and Medium Scale Enterprises (SMEs) in Nigeria. International Journal of Finance and Accounting, 1(1), 8-17.

64. Terziovski, M. (2010). Innovation practice and its performance implications in small and medium enterprises (SMEs) in the manufacturing sector: a resourcebased view. Strategic Management Journal, 31(8), 892-902.

65. Tumaini, M. K., \& Zheng, Q. (2011). Supply Chain Management
(SCM) and Small and MediumSized Enterprises (SMEs): Is it a Myth? Applied Mechanics and Materials, 58-60, 2613-2620.

66. Urban, B., \& Naidoo, R. (2012). Business sustainability: empirical evidence on operational skills in SMEs in South Africa. Journal of Small Business and Enterprise Development, 146-163.

67. Van Eeden, S., Viviers, S., \& Venter, D. (2003). A comparative Study of selected problems encountered by small businesses in the Nelson Mandela, Cape Town and Egoli metropoles. Journal of South African institute for management statistics, 12(3), 13-23.
68. Watkins, J. A. (2012). Theses/ Dissertations / Research Reports: a Practical guide for students to the preparation of written presentations of academic research. Cape Town: Content Solutions.

69. Watt, J. (2007). Strategic risk management for small businesses. In Reuvid, J. (Ed.). Managing Business Risk- a practical guide to protecting your business. $2^{\text {nd }} \mathrm{Ed}$. London - Philadelphia: Kogan Page.

70. Yanta, T. (2001). Local government supporting or stunting SMME growth? University of Natal, Centre for Applied and Social Sciences. Indicator South Africa: A Barometer of Social Trend, 18(2), 44-48. 